\title{
EEN BELANGRIJKE VONDST OP BALI \\ DOOR
}

Dr. N. J. KROM.

Door de vriendelijkheid van den Heer L. Berkhout, AssistentResident van \%uid-Bali, zijn wij in de gelegenheid hier melding te maken van een vondst van buitengewone beteekenis op oudheidkundig gebied. Genoemcle heer toch deed ons een viertal foto's toekomen van een monument dat, hoewel bij de bevolking niet onbekend, tot dusver aan het oudheidkundig onderzoek ontsnapt was. Het schijnt niet meer of minder te zijn dan de bijzettingsplaats van een der oude Balische koningen.

Deze oudheid bevinclt zich in het district Tampaksiring der onderafdeeling Gianjar, en wel aan de beide oevers van de rivier Pekkarisan. Negen groote nissen zijn er in den rotswand uitgehouwen, vijf naast elkander aan den linkeroever, en vier aan den rechteroever, en in elk van die nissen is een tempelfaçade uitgespaard. De hierbijgevoegde afbeelding (naar de opname van het districtshoofd van Oeboed, Tjakorde Gde Raka) geeft van den aard dezer nissen een denkbeeld.

De stijl der weergegeven monumentjes getuigt reeds dadelijk van den hoogen ouderdom dezer overblijfselen en bewijst, dat de bevolking ze niet ten onrechte voor de oudste der geheele afdeeling houdt. Dit opzichzelf zou de vondst reeds merkwaardig genoeg maken, want, zooals bekend is, is Bali zeer arm aan oude bouwwerken, en verschaft alles, wat er van dien aard aangetroffen wordt, hoogst welkom materiaal voor het nagaan der ontwikkeling van de Balische kunst en haar verhouding tot de Hindoe-Javaansche.

$\mathrm{Er}$ is echter nog heel wat meer. Op het meest linksche der vijf gebouwtjes ${ }^{1}$ ) staat in een ook van Java bekencle, gefigureerde schriftsoort het volgende opschrift:

1) Op de foto lijken ook andere nissen schriftteekens te dragen; in het b:jgevoegd bericht wordt dairvan echter niet gerept. 


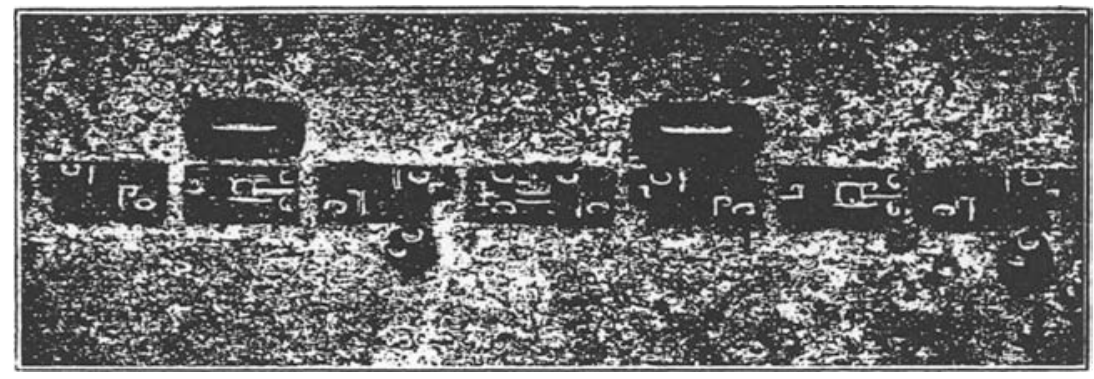

Opschrift in de uiterste linkernis.

Wij lezen dit:

haji lumāh ing Jalu

d.i.: de vorst, bijgezet te Jalu (Djaloe).

Ook op enkele oorkonden blijkt haji als titel der Balische koningen in gebruik te zijn geweest, terwijl lumah ing de hier zoowel als op Java gebezigde uitdrukking voor een bijzetting is. In het bijzonder op Bali schijnt men aan den vorm met lange $\overline{\mathbf{a}}$ de voorkeur te hebben gegeven. In ieder geval duidt het opschrift deze plek hoogstwaarschijnlijk aan als de bijzetplaats van een Balischen koning, die naar gewoonte in het vervolg niet meer met zijn eigen naam, doch met dien zijner begraafplaats werd genoemd. Jalu (Djaloe) z.ou dan de oude naam van dit grafheiligdom zijn geweest.

Van elders is deze vorst ons niet bekend, doch misschien komt hij voor op een der in de laatste jaren op Bali ontdekte, nog niet gepubliceerde koper-oorkonden. Gelukkig bevat de lettersoort een aanwijzing voor de dateering; $z i j$ is op Java in onze elfde eeuw, vooral de eerste helft daarian, in gebruik geweest. Op het epigrafische belang van het feit, dat zij thans ook op Bali inheemsch blijkt te zijn geweest - tot dusver was zij er slechts gevonden op een enkel beeld ${ }^{1}$ ), dat eventueel van Java ingevoerd had kunnen zijn - kunnen wij hier nict nader ingaan; doch een voorloopige dateering in ongeveer dienzelfden tijd vindt steun in de omstandigheid, dat wij uit de tweede helft der tiende en eerste helft der elfde eeuw ook van Java een paar voorbeelden van bijzetting in verband met een waterwerk hebben, zij het dan ook een badplaats en geen riviertje ${ }^{2}$ ).

1) Op den Panoelisan; zie Ned. Indië, Oud en Nieuw, V (1920), p. 11.5, noot 2

3) Djalatoenda en Bèlahan; rgl. Inleiding tot de Hindoe-Javaansche kunst (1920), I p. $405-411$. 
Ginds werd de lijkurn gevonden midden onder den vloer der badplaats, zoodat het water er overheen stroomde; mogelijk is naar analogie daarvan de veronderstelling niet al te gewaagd, dat te $\mathrm{Djaloe}$ de vorstelijke asch onder de bedding der rivier midden tusschen de nissenreeksen rust.

Niet het minst merkwaardige is hetgeen deze oudheid ons biedt in kunsthistorisch opzicht, en wel in den dakvorm der afgebeelde monumentjes. De Hirdoe-Javaansche kunst vertoont een gaping tusschen de in verdiepingen opgetrokken daken met min of meer losstaande daktorentjes van het Midden-Javaansche tijdperk, en de uit horizontale lagen samengestelde Oost-Javaansche daken, waarbij versierde banden afwisselen met reeksen zoogenaamde voetstuk-ornamentjes. De ontbrekende tusschenvorm wordt ons nu verschaft door deze Balische tempeltjes, waar de als voetstuk behandelde daktorentjes nog ivel afzonderlijke bouvdeelen vormen, maar toch reeds gereed staan om hun plaats tusschen de horizontale daklagen te gaan innemen. Chronologisch instaande tusschen de ons bekende Midden- en Oost-Javaansche daken, hebben de nistempeltjes van Djaloe klaarblijkelijk bewaard hetgeen op Java voor ons verloren is gegaan, en leveren zij tegelijkertijd een bewijs voor den nauwen samenhang tusschen de Hindoe-kunst van Java en van Bali.

Blijkens één der foto's bevindt zich naast de vijf nissen nog een ander, eveneens uit den rotssteen gehouwen monument, dat den indruk maakt van drie door muurtjes verbonden gebouwtjes, waarvan het middelste, tevens kleinste, een poortje is. Met hun onversierde wanden en gladde daken wekken deze gebouwtjes de herinnering aan de Javaansche Tjandi Vringinbrañdjang ${ }^{1}$ ); of dit meer dan een oppervlakkige gelijkenis is, en wat de ware beteekenis van dit monument is, zal eerst door later onderzoek kunnen worden uitgemaakt. In het algemeen geldt natuurlijk van al deze overblijfselen, dat slechts een nauwkeurige oudheidkundige opname alle gegevens tot hun recht kan doen komen. Het in elk geval buitengewone belang van het graf heiligdom van Djaloe maakte het echter wenschelijk, reeds dadelijk deze ontdekking wereldkundig te maken.

1) Inleiding enz., II p. 206-208, en plat 82 . 